\title{
Islamic Religious Narrative on Social Media Regarding the Implementation of Community Activity Restriction Policy (PPKM) in Indonesia
}

\author{
Nur Hasyim ${ }^{1}$, Akhriyadi Sofian², Kaisar Atmaja ${ }^{3}$, \\ Misbah Zulfa Elizabeth ${ }^{4}$, Naili Ni'matul Illiyyun ${ }^{5}$ \\ Faculty of Social and Political Science UIN Walisongo Semarang
}

\begin{abstract}
Social media is becoming a space for contesting Islamic religious narratives regarding the implementation of Community Activity Restriction Policy (PPKM). The contestation in the virtual realm represents the contestation of people's religious views in the real life that affect the implementation of PPKM policy in Indonesia. This paper investigates the Islamic religious narratives of the Indonesian people on social media regarding the implementation of the PPKM policy which has been implemented between $3^{\text {rd }}$ and $20^{\text {th }}$ of July 2021. Applying netnography, This paper aims to answer the following questions 1) What are the dominant religious narratives related to PPKM policy that emerge on social media? 2) How are those religious narrative expressed? 3) Why did the dominant religious narrative emerge? This paper found that the Islamic religious narrative related to PPKM is dominated by two different narratives, namely the supporting and the opposing narrative towards the PPKM policy. These different narratives are influenced by two things, first, the orientation of religious thought, secondly interests and political affiliations. The supporting narratives toward PPKM are characterized by a substantive religious orientation and interest to put religion within the constitutional framework and therefore support the government policy, while the opposing narratives against PPKM policy is characterized by a symbolic religious orientation and oppositional interests to the government.
\end{abstract}

Keywords: Religious Narrative; Media Social; Community Activity Restriction Policy

\section{Introduction}

Restrictions on community activities as a result of the spike in the increasing spread of Covid-19 have been set, starting from July 3 to 20, 2021. Several government regulations after presidential circulars enactment were launched. Governor and mayors/regents' regulations elaborated the higher decrees into a more local one. The points specified in the restriction are in principle to prevent crowding activities. Therefore, it is explicitly stated that places of worship are temporarily closed from routine worship activities, as well as supporting worship activities at home. It was also emphasized that family events such as weddings were limited in 
the number of attendees, and this number was even banned from holding events in the later regulation. Of the two points set out in several provisions for restricting community activities, the ones that received the most responses were points related to restrictions on religious activities. The response appeared in various communication platforms in cyberspace, including Twitter and Instagram.

Some of the studies related to social media response toward any social processes, for example done by Abedin and Babar (2018). They studied the use of social media during the all-phase fire disaster that occurred in Australia state of Victoria in early February 2014. The study found the power of social media platforms like Twitter in disseminating disaster information. The platform used both institutionally and non-institutionally. Haman (2020) found in his research that so how many leaders used Twitter during the COVID-19 pandemic. It impacted the increased interest of the public about information on pandemic. This study is in line with the study of Tsao et al. (2021) who found that social media has rapidly become a crucial communication tool for information generation, dissemination, and consumption. Based on the facts and studies above, this study aims to reveal: ) What are the dominant religious narratives related to PPKM policy that emerge on social media? 2) How are those religious narrative expressed? 3) Why did the dominant religious narrative emerge?

Assuming that the use of platforms in cyberspace is a phenomenon commonly used in today's digital era, it is possible to use virtual world communication platforms as a medium to capture people's ideas. The next assumption is that due to the specific mention of activities in places of worship, in the PPKM-Emergency regulation, in the context of the diverse Indonesian society, various reactions will arise, not all of which are supportive of the government's decision. The last assumption is that the use of verbal and visual expressions in virtual world communication platforms describes the background of the presenter and general conditions in society

\section{Literature Review}

Some scholars conduct research on PPKM in different focuses and approaches. The effectiveness of PPKM in tackling Covid-19 virus has been observed by Thorik (2020); Nawangsari et al (2021), Nelwan (2021) and so forth. Pujaningsih et al (2020) state that PPKM in Denpasar was successfully implemented and supported by local leaders and society. Participation of society in reducing the spread of Covid-19 virus during PPKM has been observed by Nawangsari et al (2021). Tri Sakti, Mohamad, and Azlan (2021) observed the expression of Indonesian people toward PSBB in the internet. Indonesians showed positive impression toward government in tackling COVID-19. There is no correlation between depression and anxiety with lockdown and COVID-19 information in social media (Cordoș and Bolboacă 2021). On the other hand, Napitu et al (2021) argue that the implementation of PPKM cannot reduce the spread of Covid-19 virus because of the lack of awareness among people. Nelwan (2021) finds that there is injustice among coffee shops' owners in terms of regulation of working hours in the midst of PPKM.

Religion and Covid-19 pandemic has been observed by several researchers such as A. Muhammad (2020), Abdullah (2020), and Alkaf (2020). Qotadah (2020) focuses on study of maqasid syariah in deferment of religious services in religious places. Aula (2020) focuses on the role of religious figures in tackling pandemic through online media. Toresano (2020) claims that religion and science have similar roles in tackling pandemic. Luhukay (2020) explains about theological analysis of doing religious services at home during Covid-19 
pandemic. Dwiraharjo (2020) and Sihotang (2020) conduct their research on the use of information technology in Christianity religious teaching, whereas Putra and Negara (2020) conduct a research on Hindus religious teaching during Covid-19 pandemic.

\section{Theoretical framework}

The government has implemented a number of policies to prevent the spread of Covid-19: PSBB, PPKM Mikro, and most recently PPKM Darurat. All these policies have an impact on many aspects of people's lives: economic, social interactions, and religious life aspects. The PPKM-policy explicitly prohibits religious practices in places of worship for people in the black and red zone areas. This situation triggers a reaction from social media users: Twitter and Instagram. There are expressions of support and oppose the banning of the closing of mosques for communal activities such as, Jum'at and Eid al-Adha prayers. Dahrendorf, in Poloma (2010) states that community groups with their various associations will experience conflict, split and be divided based on their interests. Interests that may not be so obvious, but will be clear when viewed as a conflict of legitimacy of authority through the power structure.

Johnson (1990) sees a relationship between the legitimacy of authority and conflicting interest groups. Interest groups within the power structure will certainly support the PPKMpolicy and the prohibition of carrying out religious practices as in normal situations. On the other hand, those outside the power structure will give different expressions (Maliki 2012). Twitter and Instagram users are individuals who come from associations that exist in society. They are parties who have a conscious (manifest) or potential (latent) interest. So that the conflict between religious narratives on social media actually represents the interests of each party. Parties who occupy certain roles in the power frame with those outside of it will of course express different narratives.

\section{Methodology}

This qualitative research uses a digital-ethnography approach or netnography. Kozinets proposed netnography as a method that is similar to ethnography but the data is from the internet (Bowler 2010; Illiyyun, Anshori, and Suyanto 2020; Kozinets 2002). Netnography allow researchers to observe the interaction through videos and memes of social media users. This research focuses on two social media platforms namely twitter and Instagram and applies three hashtags key words (\#) which are \#prayfromhome \#ibadahdirumah \#masjidditutup. According to Latzko-Toth, Bonneau, and Millette (2017) qualitative method in social media research consists of three ways: trace interview, manual data collection, and long-term online observation. All primary data are collected from all relevant comments on those selected key words. Lupton (2015) argued that digital-data which is produced and saved is vital to understand the new social data. Data collected are text and visual data both video and meme. Those three hashtags in twitter and Instagram are to know the contestation of ideas amongst internet users to respond government policy in handling pandemic covid-19 particularly the PPKM-policy. 


\section{Result and Discussion}

The Government of Indonesia has issued a Policy on Community Activity Restrictions (PPKM) for Java and Bali island on July 3, 2021 through the Instruction of the Minister of Home Affairs No. 15 of 2021. One of the points of this policy is that places of worship and other public places that function as places of worship are temporarily closed as stated in the section three, point $\mathrm{g}$ of the policy. This point has triggered religious debates in society, both in the offline and online realm.

\section{a) The Islamic Religious Narrative on PPKM-Policy}

Using three hashtags; \#prayfromhome, \#masjiddiclosed, and \#iduladhadirumah as keywords, this study found two dominant Islamic religious narrative that appeared on Instagram and Twitter related to PPKM-policy.

First, religious narratives that support the policy of closing places of worship (in the context of this study is mosques) and performing activity of worship at home. This first narrative is reflected in several top posts both on twitter and on Instagram with a fairly high level of social media user involvement when viewed from views, comments, likes and shares. Among the narratives that support the PPKM-policy are 1) Emergency conditions, such as during pandemic, are the syar'i reasons for changing mandatory worship procedures. 2) Obedience to the government is a form of carrying out religious orders 3) Spiritual activities at home such as praying is complementary of prevention efforts through the implementation of health protocols. 4) For Muslims, their obligation is performing sholat (praying) five times a day, not congregational prayers at the mosque 5) Worship at home such as performing dzuhur prayer at home to replace Friday prayers and conducting prayers Eid al-Adha at home with family members is the implementation of religious order to prevent pandemic.

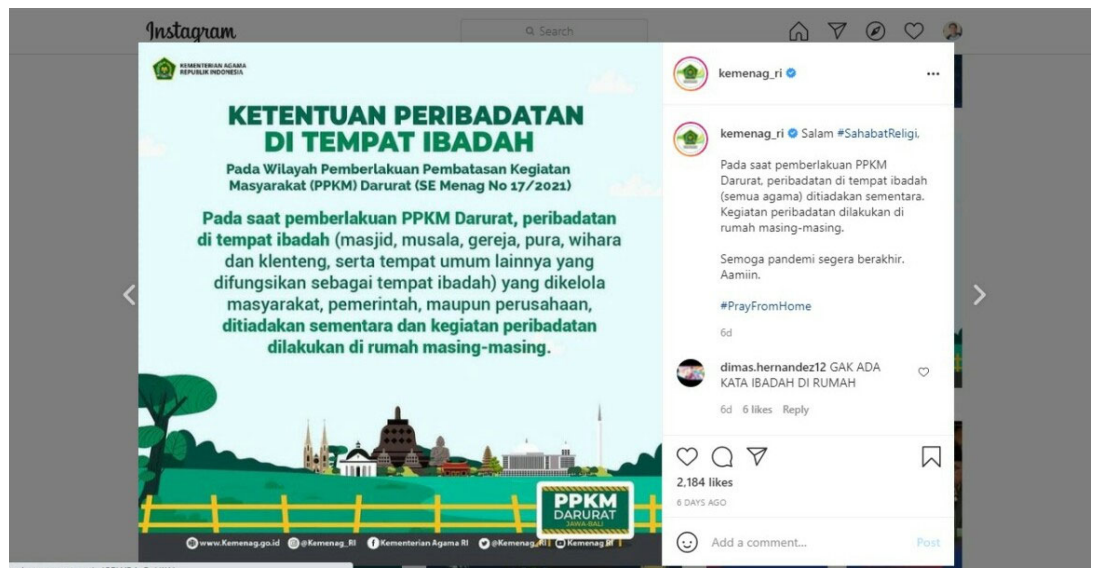

Source: instagram account of ministry of religious affairs@kemenag_ri, 2021

Fig. 1. Policy to do pray from home

The second dominant religious narrative is the narrative that oppose the PPKM-policy. Among the narratives are 1) refusing the closure of mosques for congregational prayers is a form of istiqomah (consistence) for Muslims 2) Worship in mosques should not be defeated 
by business activities such as malls and markets 3) closing mosques is a form of discrimination against Muslims 4) closing mosques offends Muslims.

\section{b) The Way Dominant Narrative Expressed}

There are two dominant narratives that are expressed in social media. They are in the form of video and poster. The both forms of narration are expressed in various ways. And the third are narratives that are expressed in the form of text.

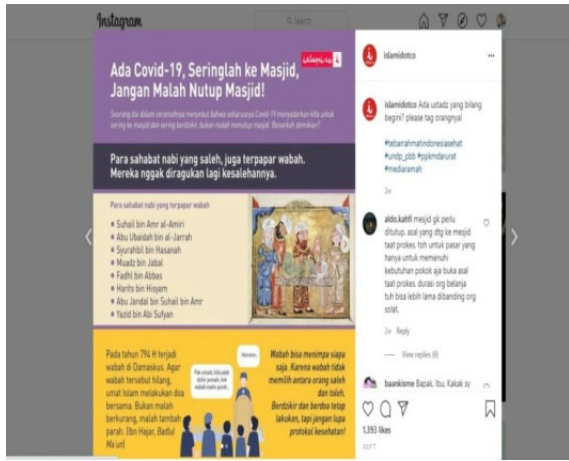

Source: instagram account of @islami.co, 2021

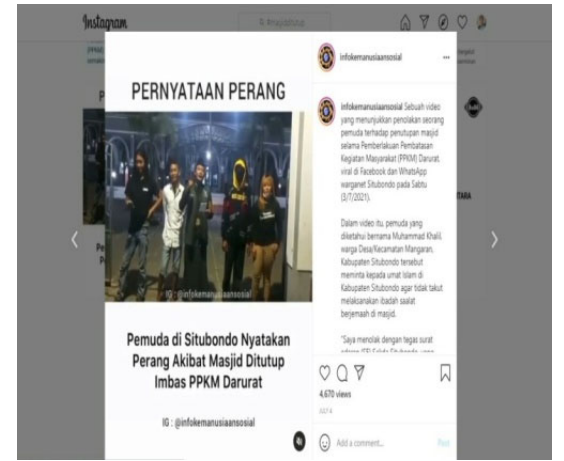

Source:https:/www.instagram.com/infokemanu siaansosial/

Fig 2. Some people/group refuse to do pray from home

Videos. There are two types of videos used, the first is video containing views and arguments used by the account owner. Second, a video containing quotes from certain religious figures whose statement supports the narrative expressed by the account owner. and posters are the two dominant media used to express religious narratives related to the PPKM policy. The example of the video containing views and arguments used by the account owner, are.
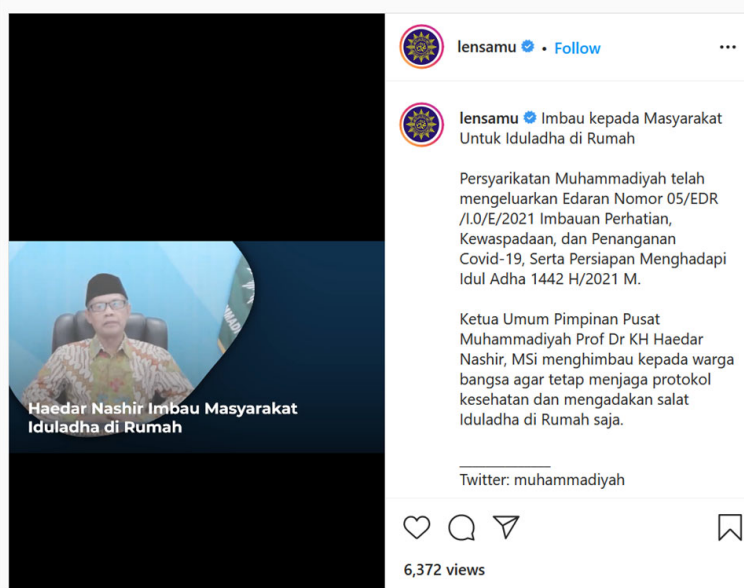

https://www.instagram.com/p/CRhAFbJhXHq/ 
Poster. For religious narratives using posters, it is expressed by presenting key messages and infographics that support religious narratives constructed by account owners.

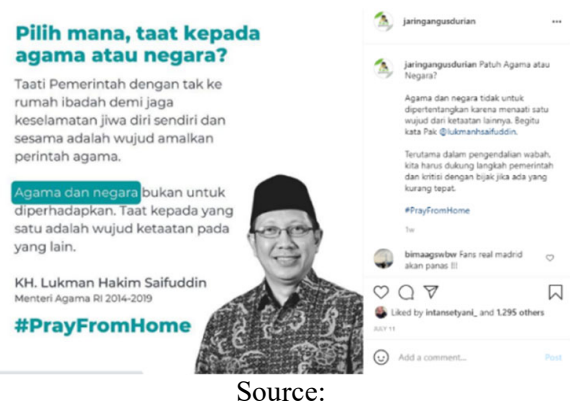

https:/www.instagram.com/jaringangusdurian/

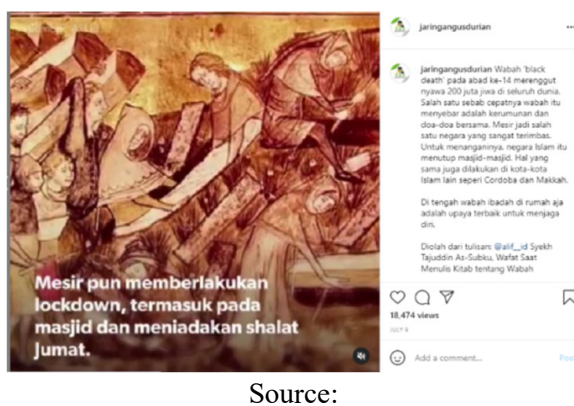

https://www.instagram.com/jaringangusdurian/

Narratives. Narratives that are expressed using text (account owner status) are carried out by public figures with large number of followers so that even though they only use text, the level of engagement is quite high.

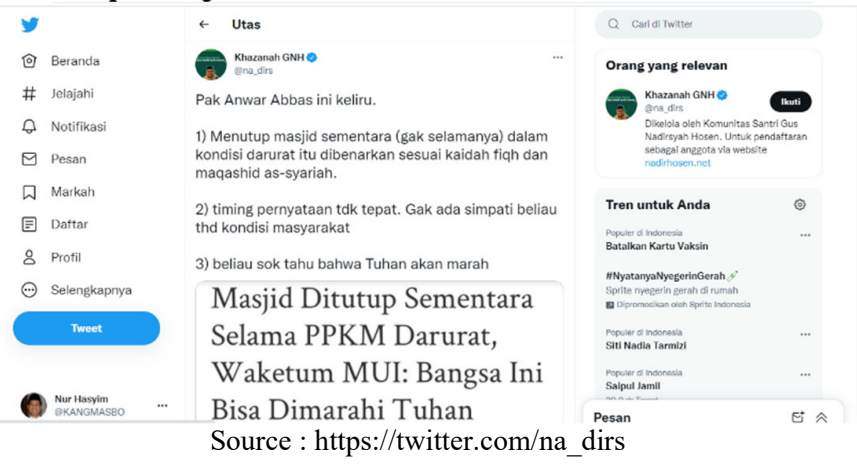

\section{c) The Reason of Dominant Narrative}

The differences in religious narratives related to the PPKM policy were driven by two things, namely the orientation of religious views and political interests and affiliations. There are two tendencies of religious orientation, substantive and symbolic. Substantive religious views refer to religious views that emphasize substantive dimensions rather than symbolic aspects of religion. It referring to universal values of religion and maqasid-sharia or the objective of religion to create the betterment of human being. The symbolic religious view refers to the religious view that emphasizes the formal symbols of religion. Referring to these two religious' orientations, the narratives that supports the PPKM-policy are characterized by a substantive religious orientation meanwhile opposite narratives are characterized by a symbolic religious orientation.

The two opposite narratives on PPKM Policy are driven by different interests and political affiliations. Religious narratives against the Emergency PPKM policy are carried out by groups who have different interest from the government and are affiliated with opposition parties in parliament. This tendency can be traced from other posts that are not related to 
Emergency PPKM. On the other hand, religious narratives that support the PPKM policy are not only promoted by government institutions, but also by groups that consider religious practices must be put within the constitution framework. This constitutional religious pattern supports a moderate, inclusive and tolerant religion.

\section{Conclusion}

This study concludes that first, Islamic religious narratives related to the implementation of PPKM policy in Indonesia are dominated by two major narratives, namely narratives that support and oppose the policy. Second, narratives of Islamic religion related to the policy are expressed in various ways. Posters and videos become the dominant form of media content used to express the narrative. Third, the different narratives about PPKM policy are driven by two important things, namely religious orientation and interests and affiliations. The two narratives are based on religious arguments with different characteristics; narratives that support the PPKM Policy characterized by substantive religiosity, while those that oppose the policy characterized by symbolic religiosity. The both narratives use religious argumentation as their justification. Narratives that support the policy are raised by institutions affiliated with the government and groups that put religion in the constitutional framework while narratives that oppose the PPKM-policy are carried out by groups that have opposing positions with the government and are affiliated with opposition parties in the parliament.

\section{References}

[1] A., Muhammad Tahir. 2020. "Nalar Agama Dan Pandemi Covid-19." Pp. 102-8 in PROSIDING SEMINAR NASIONAL PROBLEMATIKA SOSIAL PANDEMI COVID-19 “Membangun Optimisme di Tengah Pandemi Covid-19." Kendari.

[2] Abdullah, M. Amin. 2020. "Mendialogkan Nalar Agama Dan Sains Modern Di Tengah Pandemi Covid-19.” MAARIF 15(1):11-39.

[3] Abedin, Babak, and Abdul Babar. 2018. "Institutional vs. Non-Institutional Use of Social Media during Emergency Response.” Information Systems Frontiers 20(4):72940.

[4] Alkaf, M. 2020. "Agama, Sains, Dan Covid-19: Perspektif Sosial-Agama.” MAARIF 15(1):93-108.

[5] Aula, Siti Khodijah Nurul. 2020. "PERAN TOKOH AGAMA DALAM MEMUTUS RANTAI PANDEMI COVID-19 DI MEDIA ONLINE INDONESIA.” Living Islam: Journal of Islamic Discourses 3(1):125-48.

[6] Bowler, Gary M. 2010. "Netnography: A Method Specifically Designed to Study Cultures and Communities Online." The Qualitative Report 15(5):1270-75.

[7] Cordoș, Ariana Anamaria, and Sorana D. Bolboacă. 2021. "Lockdown, Social Media Exposure Regarding COVID-19 and the Relation with Self-Assessment Depression and Anxiety. Is the Medical Staff Different?" International Journal of Clinical Practice 75(4).

[8] Dwiraharjo, Susanto. 2020. "Konstruksi Teologis Gereja Digital: Sebuah Refleksi Biblis Ibadah Online Di Masa Pandemi Covid-19." EPIGRAPHE: Jurnal Teologi Dan Pelayanan Kristiani 4(1):1-17.

[9] Haman, Michael. 2020. "The Use of Twitter by State Leaders and Its Impact on the 
Public during the COVID-19 Pandemic." Heliyon 6(11):e05540.

[10] Illiyyun, Naili Ni'matul, Ahmad Afnan Anshori, and Helmi Suyanto. 2020. "Aisnusantara: Kontribusi Santri Membangun Narasi Damai Di Era Digitalisasi Media.” JSW (Jurnal Sosiologi Walisongo) 4(2):165-86.

[11] Johnson, Doyle Paul. 1990. Teori Sosiologi Jilid 1\&2 : Klasik Dan Modern. Jakarta: PT Gramediia Pustaka Utama.

[12] Kozinets, Robert V. 2002. "The Field behind the Screen: Using Netnography for Marketing Research in Online Communities." Journal of Marketing Research 39(1):61-72.

[13] Latzko-Toth, Guillaume, Claudine Bonneau, and Mlanie Millette. 2017. "Small Data, Thick Data: Thickening Strategies for Trace-Based Social Media Research.” Pp. 199214 in The SAGE Handbook of Social Media Research Methods, edited by L. Sloan and A. Quan-Haase. London: SAGE Publications Ltd.

[14] Luhukay, Alexander Stevanus. 2020. "ANALISIS TEOLOGIS MENGENAI BERIBADAH DI RUMAH DI TENGAH PANDEMI COVID-19 DI INDONESIA." VISIO DEI: JURNAL TEOLOGI KRISTEN 2(1):43-61.

[15] Lupton, Deborah. 2015. Digital Sociology. London: Routledge.

[16] Maliki, Zainuddin. 2012. Rekonstruksi Teori Sosial Modern. Yogyakarta: | UGM PRESS - Badan Penerbit dan Publikasi Universitas Gadjah Mada.

[17] Napitu, Ulung, Corry Corry, and K. D. Matondang. 2021. "SOSIALISASI PEMBATASAN PELAKSANAAN KEGIATAN MASYARAKAT (PPKM) MIKRO DI KELURAHAN BAH KAPUL." Community Development Journal: Jurnal Pengabdian Masyarakat 2(2):232-41.

[18] Nawangsari, Ertien Rining, Ardha Wildan Rahmadani, Nosa Yudha Firmansyah, and Zachary Arif Yovi. 2021. "Partisipasi Masyarakat Kelurahan Jelakombo Terhadap Pemberlakuan Pembatasan Kegiatan Masyarakat (PPKM) Skala Mikro Di Kabupaten Jombang." Jurnal Syntax Transformation 2(5):593-605.

[19] Nelwan, Gerry. 2021. "RESPONS PEMILIK RUMAH KOPI TERKAIT PPKM DAN PELAKSANAANNYA DI KOTA MANADO: SUATU ANALISIS DARI TEORI KONFLIK SOSIAL KARL MARX"." PUTE WAYA: Sociology of Religion Journal 2(1):17-28.

[20] Poloma, Margaret M. 2010. Sosiologi Kontemporer. Jakarta: Rajawali Pers.

[21] Pujaningsih, Ni Nyoman, and I. G. A. A. Dewi Sucitawathi P. 2020. "PENERAPAN KEBIJAKAN PEMBATASAN KEGIATAN MASYARAKAT (PKM) DALAM PENANGGULANGAN WABAH COVID-19 DI KOTA DENPASAR." Moderat: Jurnal Ilmiah Ilmu Pemerintahan 6(3):458-70.

[22] Putra, I. Nyoman Buda Asmara, and Gede Agus Jaya Negara. 2020. "Implementasi Metode Sad Dharma Penyuluhan Agama Hindu Pada Masa Pandemi Covid-19." Maha Widya Duta: Jurnal Penerangan Agama 2(2):170-80.

[23] Qotadah, Hudzaifah Achmad. 2020. "Covid-19: Tinjauan Maqasid Al-Shariah Terhadap Penangguhan Pelaksanaan Ibadah Shalat Di Tempat Ibadah (Hifdz Al-Nafs Lebih Utama Dari Hifdz Al-Din?)." SALAM: Jurnal Sosial Dan Budaya Syar-I 7(7):659-72.

[24] Sihotang, Hermanto. 2020. "Penggunaan Media Teknologi Informasi Dalam Pembelajaran Pendidikan Agama Kristen Di Masa Pandemi Covid-19." IMMANUEL: Jurnal Teologi Dan Pendidikan Kristen 1(2):63-75.

[25] Thorik, Sylvia Hasanah. 2020. "Efektivitas Pembatasan Sosial Berskala Besar Di Indonesia Dalam Penanggulangan Pandemi Covid-19.” 'Adalah: Buletin Hukum Dan 
Keadilan 4(1):115-20.

[26] Toresano, Wa Ode Zainab Zilullah. 2020. "Integrasi Sains Dan Agama: Meruntuhkan Arogansi Di Masa Pandemi Covid-19.” MAARIF 15(1):231-45.

[27] Tri Sakti, Andi Muhammad, Emma Mohamad, and Arina Anis Azlan. 2021. "Mining of Opinions on COVID-19 Large-Scale Social Restrictions in Indonesia: Public Sentiment and Emotion Analysis on Online Media." Journal of Medical Internet Research 23(8):e28249.

[28] Tsao, Shu-Feng, Helen Chen, Theresa Tisseverasinghe, Yang Yang, Lianghua Li, and Zahid A. Butt. 2021. "What Social Media Told Us in The Time of COVID-19: A Scoping Review." The Lancet. Digital Health 3(3):e175-94. 